\title{
Antioxidant activity of St. John's Wort extracts obtained with ultrasound-assisted extraction
}

\author{
Aktywność antyoksydacyjna ekstraktów z ziela dziurawca zwyczajnego otrzymanych \\ w wyniku ekstrakcji wspomaganej ultradźwiękami
}

\author{
Anna Muzykiewicz ${ }^{\bowtie}$, Katarzyna Florkowska, Anna Nowak, Joanna Zielonka-Brzezicka, Adam Klimowicz \\ Pomorski Uniwersytet Medyczny w Szczecinie, Katedra i Zakład Chemii Kosmetycznej i Farmaceutycznej, al. Powstańców Wlkp. 72, 70-111 Szczecin \\ Pomeranian Medical University in Szczecin, Chair and Department of Cosmetic and Pharmaceutical Chemistry \\ $\triangle$ anna.muzykiewicz@pum.edu.pl
}

\begin{abstract}
Introduction: St. John's Wort (Hypericum perforatum L.) is a plant from the Hypericaceae family commonly occurring in Europe, Asia, Africa and North America. It is used for medical purposes, for example in depression, viral or bacterial diseases, as well as diseases of the digestive system. St. John's Wort is a source of hypericin as well as flavonoids useful to reduce the harmful effects of free radical action.

The aim of the study was to evaluate the antioxidant activity of alcoholic and aqueous extracts of $H$. perforatum.

Materials and methods: St. John's Wort extracts were prepared in ethanol, methanol and isopropanol (each of 40\%, 70\% (v/v) and undiluted) and in water, with ultrasound-assisted extraction. Plant samples were extracted for 15, 30 and $60 \mathrm{~min}$, and the antioxidant potentials of the extracts evaluated using 2,2-diphenyl-1-picrylhydrazyl (DPPH) aand ferric reducing antioxidant power (FRAP).
\end{abstract}

Results: All the extracts showed antioxidant activity. In the case of the DPPH evaluation, the results ranged 2.42-4.37 mg trolox/g of raw material, which corresponds to $53.89-91.98 \%$ radical scavenging activity (RSA). The highest results were obtained for samples extracted for $60 \mathrm{~min}$, with the antioxidant activity of most of them above $4.00 \mathrm{mg}$ trolox/g of raw material. In the case of FRAP evaluation, the reducing power of the extracts ranged 1.40-37.82 $\mathrm{mg} \mathrm{FeSO} 4 / \mathrm{g}$ of raw material, with the highest results found for samples prepared in undiluted methanol. In contrast, the antioxidant capacity of the aqueous extracts was low. Conclusions: St. John's Wort herb showed high antioxidant activity. In most cases, higher potentials were found for the extracts prepared in undiluted alcohols. The type of solvent used and the extraction time influenced the antioxidant properties of the extracts.

Keywords: Hypericum perforatum L.; DPPH; FRAP; antioxidant activity; ultrasound-assisted extraction.

\begin{abstract}
ABSTRAKT
Wstęp: Dziurawiec zwyczajny (Hypericum perforatum L.) jest rośliną z rodziny dziurawcowatych powszechnie występującą na terenach Europy, Azji, Afryki i Ameryki Północnej. Wykorzystywana jest jako surowiec leczniczy np. w depresji, chorobach wirusowych, bakteryjnych czy schorzeniach układu pokarmowego. Ziele dziurawca jest źródłem hiperycyny, a także flawonoidów przydatnych w redukowaniu negatywnych skutków działania wolnych rodników.

Celem pracy była ocena aktywności antyoksydacyjnej alkoholowych i wodnych wyciągów z H. perforatum.

Materiały i metody: Analizie poddano ekstrakty z ziela dziurawca sporządzone w etanolu, metanolu i izopropanolu (każdy $\mathrm{w}$ trzech stężeniach $-40 \%, 70 \%$ (v/v) i nierozcieńczony) oraz w wodzie. Ekstrakty otrzymano w wyniku działania ultradźwięków przez 15, 30 i 60 min, natomiast ich potencjał antyoksydacyjny oceniono przy użyciu 2,2-difenylo-1-pikrylohydrazylu (DPPH) i oznaczania zdolności redukowania jonów żelaza (FRAP).
\end{abstract}

\section{INTRODUCTION}

St. John's Wort (Hypericum perforatum L.) is a widely distributed plant of the Hyperiacaceae family, found commonly in Europe, Asia, Africa and North America, mainly in dry and
Wyniki: Wszystkie wyciągi wykazywały aktywność przeciwutleniającą. W przypadku metody DPPH mieściła się ona w zakresie 2,42-4,37 mg troloksu/g surowca, co odpowiada RSA (radical scavenging activity) na poziomie 53,89-91,98\%. Najwyższe wyniki uzyskano dla prób ekstrahowanych przez 60 min, których większość wykazywała aktywność na poziomie ponad 4,00 mg troloksu/g surowca. W przypadku metody FRAP zdolności redukujące ekstraktów wahały się w zakresie 1,40-37,82 mg FeSO4/g surowca, przy czym najwyższe wyniki uzyskano dla prób sporządzonych w stężonym metanolu. Z kolei wyciągi wodne wykazywały słaby potencjał antyoksydacyjny.

Wnioski: Ziele dziurawca charakteryzuje się wysoką aktywnością antyoksydacyjną. W większości przypadków wyższy potencjał wykazują wyciągi sporządzone w nierozcieńczonych alkoholach. Rodzaj zastosowanego rozpuszczalnika oraz czas ekstrakcji wpływają na właściwości przeciwutleniające wyciągów. Słowa kluczowe: Hypericum perforatum L.; DPPH; FRAP; aktywność antyoksydacyjna; ekstrakcja wspomagana ultradźwiękami. sunny fields, meadows and forests. The stem of the plant is characterized by opposing leaves and can reach a height of $60 \mathrm{~cm}$. Yellow star-shaped flowers are located at the tops of the shoots $[1$, 2]. Flowering shoots of St. John's Wort are used as medicinal raw material, from which oil or alcohol extracts are made [3]. 
The properties of St. John's Wort are among the best-studied and most-described herbs. Extracts from this plant are characterized by health-promoting properties, and preparations containing this herb are very popular in Europe and the United States [4]. St. John's Wort contains a lot of biologically active compounds, of which the most commonly described appear to be hypericin and pseudohypericin (Fig. 1) and their derivatives, belonging to the naphthodianthrone group. In addition, flavonoids (including quercetin, kaempferol, luteolin), phloroglucinol derivatives (including hyperforin and adhyperforin) as well as xanthones and tannins are present in this plant. Moreover, this herb is a source of essential oil [2, $5,6]$. Preparations containing hypericin, hyperforin and biflavonoids (apigenin) are primarily used as anti-depressants [7]. In addition, there are several reports on the antiviral, antibacterial and anticancer properties of St. John's Wort extracts. Preparations containing this plant can be also used as agents supporting wound healing and to prevent the development of Alzheimer's disease, as well as to support the treatment of gastrointestinal disorders, such as stomach mucosa inflammation $[3,4,8]$.<smiles></smiles>

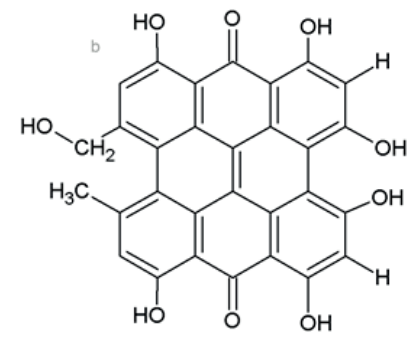

FIGURE 1. Chemical structures of: a) hypericin; b) pseudohypericin

As previously mentioned, St. John's Wort is a source of flavonoids, a group of compounds with proven antioxidant activity. Their content in this plant varied $2-5 \%$ [6]. Taking into account the negative impact of oxidative stress on the body and the protective effect of antioxidants, it seems to be important to search for natural sources of antioxidants. There are numerous reports confirming the antioxidant potential of extracts made from $H$. perforatum $[9,10,11]$. However, when using preparations containing St. John's Wort extracts, the possibility of adverse effects, including digestive tract disorders as well as skin reactions, mainly due to the photosensitizing potential of hypericin and pseudohypericin, should be also taken into account [3]. In addition, these substances may interact with other drugs applied in the treatment of cardiovascular or digestive system disorders, or with anti-inflammatory, anticancer or antimicrobial preparations [4].

The aim of the study was to determine the antioxidant activity of $H$. perforatum extracts prepared by ultrasound-assisted extraction. The impact of the kind of solvent, the concentration and duration of the extraction process on the antioxidant potential of the obtained extracts were also evaluated.

\section{MATERIALS AND METHODS}

2.2-diphenyl-1-picrylhydrazyl (DPPH), 2,4,6-Tris(2-pyridyl)s-triazine (TPTZ), 6-Hydroxy-2,5,7,8-tetramethylchroman2-carboxylic acid (trolox) were purchased from Sigma Aldrich, USA; iron (III) chloride hexahydrate and iron (II) sulfate heptahydrate were from Merck Darmstadt, Germany, 36\% hydrochloric acid, anhydrous sodium acetate, potassium persulfate, methanol, isopropanol and $99.5 \%$ acetic acid, all of p.a. purity, were from Chempur, Piekary Śląskie, whereas ethanol from Linegal Chemicals, Poland.

The plant raw material consisted of the entire aboveground part of fresh St. John's Wort, i.e. stem, leaves, and flowers, harvested from agricultural wasteland located in Szczecin at the beginning of the flowering period, in June 2017. To obtain $5 \%$ extracts, ultrasound-assisted extraction for 15,30 and $60 \mathrm{~min}$ at room temperature were used with the following solvents: distilled water, $40 \%, 70 \%$ and $99.8 \%(\mathrm{v} / \mathrm{v})$ methanol, $40 \%$, $70 \%$ and $96 \%(\mathrm{v} / \mathrm{v})$ ethanol and $40 \%, 70 \%$ and $99.7 \%(\mathrm{v} / \mathrm{v})$ isopropanol. The antioxidant potential of $5 \%$ extracts were evaluated using DPPH and ferric reducing antioxidant power (FRAP) techniques as described previously $[12,13,14]$. Three independent samples were prepared for each extract. In the case of DPPH method, the results are expressed as an arithmetical mean ( \pm standard deviation - SD) of radical scavenging activity (\%RSA) as well as an arithmetical mean $( \pm \mathrm{SD})$ of trolox equivalents (mg trolox/g raw material). For FRAP method, the results are presented as the arithmetical mean $( \pm S D)$ of iron (II) sulfate equivalents $-\mathrm{mg} \mathrm{FeSO} 4 / \mathrm{g}$ raw material.

The differences between the antioxidant activity of extracts determined by each method were evaluated using the Wilcoxon test assuming a level of significance of $\alpha=0.05$. Moreover, Pearson's correlation coefficients between the results obtained with FRAP and DPPH methods were calculated. Statistical analysis was performed using Statistica 12 (StatSoft, Poland) and Prostat 5.5 (Poly Software International, Inc. USA).

\section{RESULTS}

All the $H$. perforatum extracts evaluated by DPPH and FRAP methods showed antioxidant activity (Tab. 1). Antioxidant potential evaluated with DPPH technique varied from 2.42 \pm 0.03 to $4.37 \pm 0.03 \mathrm{mg}$ trolox/g of raw material (corresponding to of $53.89 \pm 0.60$ to $91.98 \pm 0.50 \%$ RSA) - Figure 2. Using DPPH method, the highest antioxidant activities of over 4.00 mg trolox/g raw material were found for the samples extracted the longest, with the exception of the water extracts $(3.56 \mathrm{mg}$ trolox/g raw material) and those prepared in $40 \%$ and $99.7 \%$ isopropanol -3.78 and $3.21 \mathrm{mg}$ trolox/g raw material, respectively. Extracts obtained with 15 and 30 min extraction showed lower activity than the extracts prepared with $1 \mathrm{~h}$ extraction, except the samples prepared in concentrated methanol: 4.19 \pm 0.02 ( $15 \mathrm{~min}$ ) and $4.23 \pm 0.04(30 \mathrm{~min}$ ) and concentrated ethanol - 4.01 $\pm 0.03 \mathrm{mg}$ trolox/g raw material (30 min) - Table 1. 
The reducing potential assessed with FRAP method ranged from $1.40 \pm 0.02$ for aqueous extracts obtained after $15 \mathrm{~min}$ extraction, to $37.82 \pm 0.11 \mathrm{mg} \mathrm{FeSO} 4 / \mathrm{g}$ raw material for extracts prepared in concentrated methanol over $60 \mathrm{~min}$. The highest activity was found for samples prepared in concentrated methanol, at all extraction times: $19.42 \pm 0.04 \mathrm{mg} \mathrm{FeSO} 4 / \mathrm{g}$ of raw material ( $15 \mathrm{~min}), 24.59 \pm 0.02 \mathrm{mg} \mathrm{FeSO} 4 / \mathrm{g}$ of raw material (30 min) and $37.82 \pm 0.11 \mathrm{mg} \mathrm{FeSO} 4 / \mathrm{g}$ raw material (60 min). In contrast, the aqueous extracts, especially those extracted during 15 and
$30 \mathrm{~min}$, showed the lowest reduction abilities, at $1.40 \pm 0.02$ and $1.74 \pm 0.02 \mathrm{mg} \mathrm{FeSO} 4 / \mathrm{g}$ of raw material, respectively.

The antioxidant activity of St. John's Wort extracts assessed by the DPPH method differed significantly from the potential determined by the FRAP technique (Wilcoxon test $\mathrm{z}=-0.638$; $\mathrm{p}<0.0001)$. However, both methods correlated with each other to a statistically significant degree $(r=0.544 ; p=0.002)$. Figure 3 shows the relationship between the results obtained with both the above-mentioned methods.

TABLE 1. Antioxidant activity of St. John's Wort extracts (mean \pm SD) determined by DPPH and FRAP methods

\begin{tabular}{|c|c|c|c|c|c|c|}
\hline \multirow{3}{*}{$\begin{array}{l}\text { Solvent } \\
(v / v)\end{array}$} & \multicolumn{3}{|c|}{$\begin{array}{c}\text { DPPH method } \\
\text { trolox equivalents } \\
\text { (mg trolox/g raw material) }\end{array}$} & \multicolumn{3}{|c|}{$\begin{array}{c}\text { FRAP method } \\
\mathrm{FeSO}_{4} / \mathrm{g} \text { equivalents } \\
\text { (mg FeSO } / \mathrm{g} \text { raw material) }\end{array}$} \\
\hline & \multicolumn{6}{|c|}{ time of ultrasound-assisted extraction (min) } \\
\hline & 15 & 30 & 60 & 15 & 30 & 60 \\
\hline $\mathrm{H}_{2} \mathrm{O}$ & $3.12 \pm 0.03$ & $3.29 \pm 0.04$ & $3.56 \pm 0.02$ & $1.40 \pm 0.02$ & $1.74 \pm 0.02$ & $7.30 \pm 0.02$ \\
\hline $\mathrm{MeOH} 40 \%$ & $3.78 \pm 0.02$ & $3.87 \pm 0.03$ & $4.03 \pm 0.03$ & $5.32 \pm 0.03$ & $7.15 \pm 0.04$ & $7.35 \pm 0.03$ \\
\hline $\mathrm{MeOH} 70 \%$ & $3.55 \pm 0.04$ & $3.87 \pm 0.04$ & $4.37 \pm 0.03$ & $5.78 \pm 0.03$ & $9.09 \pm 0.05$ & $14.72 \pm 0.07$ \\
\hline $\mathrm{MeOH} 99.8 \%$ & $4.19 \pm 0.02$ & $4.23 \pm 0.04$ & $4.23 \pm 0.03$ & $19.42 \pm 0.04$ & $24.59 \pm 0.02$ & $37.82 \pm 0.11$ \\
\hline EtOH 40\% & $2.75 \pm 0.04$ & $3.49 \pm 0.04$ & $4.34 \pm 0.03$ & $3.71 \pm 0.13$ & $6.96 \pm 0.09$ & $9.21 \pm 0.03$ \\
\hline EtOH $70 \%$ & $3.24 \pm 0.03$ & $3.65 \pm 0.03$ & $4.09 \pm 0.03$ & $5.43 \pm 0.02$ & $7.62 \pm 0.04$ & $9.23 \pm 0.04$ \\
\hline EtOH 96\% & $3.67 \pm 0.03$ & $4.01 \pm 0.03$ & $4.21 \pm 0.04$ & $11.79 \pm 0.01$ & $25.77 \pm 0.05$ & $33.43 \pm 0.09$ \\
\hline IsoProOH $40 \%$ & $3.61 \pm 0.03$ & $3.66 \pm 0.02$ & $3.78 \pm 0.05$ & $5.75 \pm 0.03$ & $6.02 \pm 0.03$ & $7.68 \pm 0.03$ \\
\hline IsoProOH 99.7\% & $2.42 \pm 0.03$ & $2.78 \pm 0.04$ & $3.21 \pm 0.04$ & $6.45 \pm 0.02$ & $11.96 \pm 0.09$ & $12.21 \pm 0.02$ \\
\hline
\end{tabular}

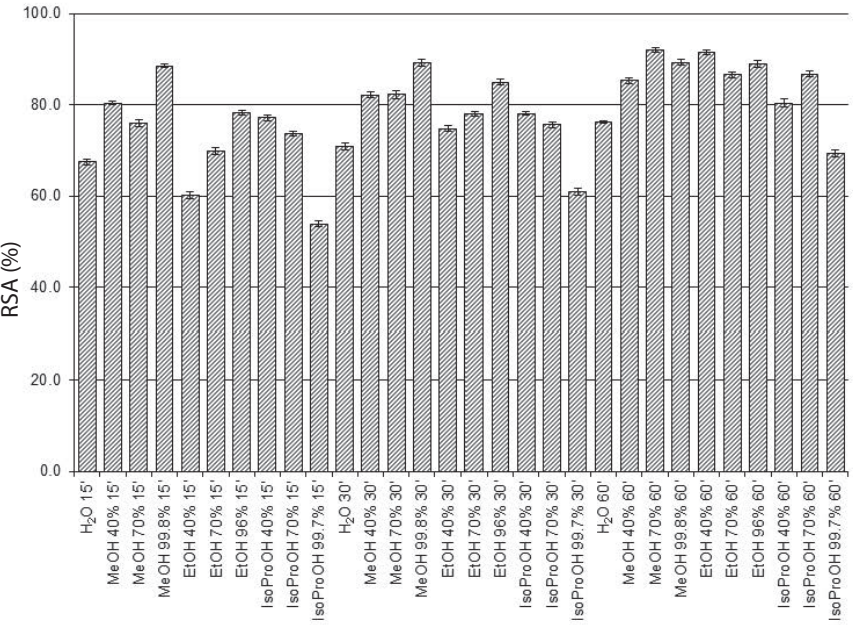

FIGURE 2. Free radical scavenging activity (\%RSA) of $H$. perforatum extracts determined by the DPPH method

\section{DISCUSSION}

St. John's Wort (Hypericum perforatum L.) is an herb widely distributed all over the world, mainly in Europe, Asia, Africa and North America. In the presented study, the antioxidant activity of the extracts of St. John's Wort harvested during the flowering period has been evaluated. To obtain extracts in 4 solvents, i.e. 40\% (v/v), 70\% (v/v) and undiluted ethanol, methanol, isopropanol as well as in distilled water, ultrasound-assisted

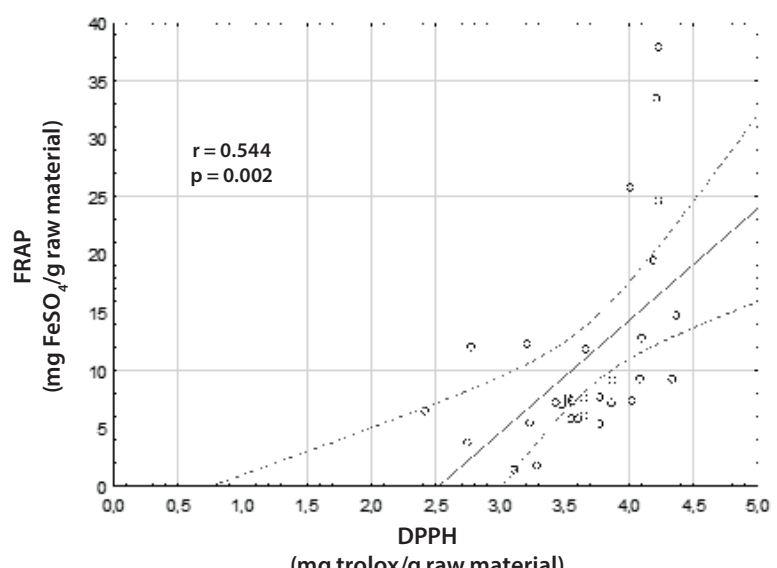

(mg trolox/g raw material)

FIGURE 3. Correlation between antioxidant potential of St. John's Wort extracts evaluated with DPPH and FRAP methods

extraction for 15, 30 or 60 min was applied. Antioxidant activity of the obtained extracts was assessed by DPPH and FRAP methods. All the extracts showed antioxidant activity evaluated with these both methods, however, this parameter differed between the samples, depending on the applied extracting and length of this process.

In case of the DPPH method, antioxidant activity ranged from $2.42 \mathrm{mg}$ trolox/g raw material, equivalent to 53\% RSA for extracts prepared in undiluted isopropanol for $15 \mathrm{~min}$, to $4.37 \mathrm{mg}$ trolox/g raw material corresponding to $91 \% \mathrm{RSA}$ 
for samples prepared in $70 \%(\mathrm{v} / \mathrm{v})$ methanol, within $60 \mathrm{~min}$. The ferric reducing capacity evaluated by the FRAP method ranged from $1.40 \mathrm{mg} \mathrm{FeSO}_{4} / \mathrm{g}_{\text {raw }}$ material for extracts prepared in water ( $15 \mathrm{~min}$ ) to $37.82 \mathrm{mg} \mathrm{FeSO}_{4} / \mathrm{g}$ raw material for extracts in concentrated methanol (60 min). Napoli et al. studied the antioxidant capacity of 11 species of Hypericum grown in Sicily. All the species had antioxidant activity ranging from 0.57 mmol trolox/g raw material for H. aegypticum L. to $3.50 \mathrm{mmol}$ trolox/g raw material for $H$. androsaemum L. [15]. Béjaoui et al. tested $H$. humifusum and $H$. perfoliatum by DPPH method and found antioxidant potentials of $84.63 \mu \mathrm{mol}$ trolox/g and 52.31 $\mu \mathrm{mol}$ trolox/g of raw material, respectively. They also observed the ferric reducing capacity of 80.23 and $50 \mathrm{mmol} \mathrm{Fe}{ }^{2+} / \mathrm{g}$ raw material for $H$. humifusum and $H$. perfoliatum, respectively. Moreover, the studied St. John's Wort species were also characterized by a high content of total polyphenols (48-113 mg gallic acid/g raw material), flavonoids (8-41 mg quercetin/g raw material) as well as hypericin and hyperforin (60-90 and 8-30 mg/g raw material, respectively) [16].

Antioxidant activity of plant extracts depends not only on the length of extraction but also on the solvent used. These factors are important parameters in the evaluation of the antioxidant activity of plant extracts $[17,18]$. Pawlak and Sielicka came to the conclusion that the differences between the antioxidant activity of the extracts in the various solvents were associated with their dissimilar polarity [19]. Sekeroglu et al. compared ethanolic and aqueous extracts prepared from different parts of St. John's Wort, i.e. flowers, stems and leaves. Ethanolic extracts of leaves (with RSA of $84 \%$ ), followed by flowers (RSA of $72 \%$ ) and stems (RSA of $54 \%$ ) showed the highest radical scavenging potential. In contrast, the corresponding values for aqueous extracts were lower $-63 \%$ for the flower, 53\% for leaf and 33\% for stem [10]. Pawlak and Sielicka evaluated the antioxidant potential of chokeberry extracts in different solvents. They found a higher content of phenolic compounds when using solvents diluted with water compared to undiluted. The most effective extractant in that case was a mixture of acetone and water (50:50 by vol.) [19]. However, in our study, higher antioxidant activities were found for extracts in undiluted alcohols, i.e. in most methanolic and ethanolic extracts, moreover, the antioxidant potential of the extracts increased with the increasing concentration of the solvent. Using the FRAP method, the activities of some tested samples in concentrated solvents were up to several times higher compared to the extracts in diluted solvents. Furthermore, in most cases the antioxidant activity of the extracts decreased if the molecular weight of the alcohol used as extractant increased. Therefore, the results of our study confirm the observations of others that the antioxidant activity is affected by the extraction time, in most cases a prolongation of the ultrasound-assisted extraction time of the raw material enhanced the antioxidant activity. Wang et al. suggested that to obtain a high content of active compounds from plants, the most optimal extraction time in the ultrasonic bath is $25 \mathrm{~min}$ with an ethanol concentration of $64 \%$ at an optimal temperature of $60^{\circ} \mathrm{C}$ [20]. However, the results of our study suggested that, regardless of the analytical method used, the optimal extraction time is $60 \mathrm{~min}$, using $70 \%$ or $99.8 \%$ methanol. It should be added that in our study, extraction was performed at an ambient temperature, which may be one the reason for the observed differences.

The antioxidant potential (assessed by DPPH and expressed as \%RSA) of extracts from various herbs, for instance marjoram (Origanum majorana L.) [21], knotweed (Polygonum aviculare L.), wormwood (Artemisia absinthium L.) and yellow sweetclover (Melilotus officinalis L.) [22] are similar. These observations may confirm the usefulness of St. John's Wort as a valuable source of natural antioxidants.

\section{CONCLUSIONS}

1. Hypericum perforatum L. is characterized by a high antioxidant activity, measured by DPPH and FRAP methods.

2. The solvent used for ultrasound-assisted extraction could influence the antioxidant activity of the extracts. A higher antioxidant activity was observed for the extracts in concentrated alcohols, especially in methanol and ethanol.

3. Longer extraction times markedly increased the antioxidant activity of the obtained extracts.

4. Due to their high antioxidant activity, St. John's Wort extracts could be used as valuable ingredients in cosmetics and pharmaceutical industries. However, some restrictions due to e.g. their photosensitizing effects, should be borne in mind.

\section{REFERENCES}

1. Ganzera M, Zhao J, Khan IA. Hypericum perforatum - chemical profiling and quantitative results of St. John's Wort products by an improved highperformance liquid chromatography method. J Pharm Sci 2002;91(3):62330. doi: 10.1002/jps.10057.

2. Dobros N. Zioła o działaniu uspokajającym i przeciwdepresyjnym. Post Fitoter 2017;18(3):215-22. doi: 10.25121/PF.2017.18.3.215.

3. Muzykiewicz A, Nowak A, Klimowicz A, Florkowska K. Fotoalergeny i związki fototoksyczne pochodzenia roślinnego. Zagrożenia i korzyści terapeutyczne. Kosmos 2017;66(2):207-16.

4. Russo E, Scicchitano F, Whalley BJ, Mazzitello C, Ciriaco M, Esposito S, et al. Hypericum perforatum: pharmacokinetic, mechanism of action, tolerability, and clinical drug-drug interactions. Phytother Res 2014;28(5):64355. doi: 10.1002/ptr.5050.

5. Barnes J, Anderson LA, Phillipson JD. St John's wort (Hypericum perforatum L.): a review of its chemistry, pharmacology and clinical properties. J Pharm Pharmacol 2001;53(5):583-600.

6. Turek S. Ziele dziurawca zwyczajnego - składniki czynne i potencjalne zastosowania lecznicze. Post Fitoter 2005;6(3-4):80-6.

7. Nowak G. Fitoterapia ośrodkowego układu nerwowego. In: Nawrot J, Nowak G, editors. Leki pochodzenia naturalnego. Poznań: Wydawnictwo Naukowe Uniwersytetu Medycznego im. Karola Marcinkowskiego; 2018. p. 9-36.

8. Ramalhete N, Machado A, Serrano R, Gomes ET, Mota-Filipe H, Silva O. Comparative study on the in vivo antidepressant activities of the Portuguese Hypericum foliosum, Hypericum androsaemum and Hypericum perforatum medicinal plants. Ind Crops Prod 2016;82:29-36. doi: 10.1016/j. indcrop.2015.12.014.

9. Becker L, Zaiter A, Petit J, Zimmer D, Karam MC, Baudelaire E, et al. Improvement of antioxidant activity and polyphenol content of Hypericum perforatum and Achillea millefolium powders using successive grinding and sieving. Ind Crops Prod 2016;87:116-23. 
10. Sekeroglu N, Urlu E, Kulak M, Gezici S, Dang R. Variation in total polyphenolic contents, DNA protective potential and antioxidant capacity from aqueous and ethanol extracts in different plant parts of Hypericum perforatum L. Indian J Pharm Educ Res 2017;51(2S):S1-S7. doi: 10.5530/ ijper.51.2s.43.

11. Katsarova M, Dimitrova S, Lukanov L, Sadakov F, Denev P, Plotnikov E, et al. Antioxidant activity and nontoxicity of extracts from Valeriana officinalis, Melissa officinalis, Crataegus monogyna, Hypericum perforatum, Serratula coronata and combinations Antistress 1 and Antistress 2. Bulg Chem Commun 2017;49(G):93-8.

12. Muzykiewicz A, Zielonka-Brzezicka J, Klimowicz A, Florkowska K. Jarząb pospolity (Sorbus aucuparia L.) jako źródło składników o potencjalnym działaniu antyoksydacyjnym - porównanie właściwości przeciwutleniających ekstraktów z liści, kwiatów i owoców. Probl Hig Epidemiol 2017;98(2):125-32.

13. Zielonka-Brzezicka J, Nowak A, Zielińska M, Klimowicz A. Porównanie właściwości przeciwutleniających wybranych części maliny właściwej (Rubus idaeus) i jeżyny europejskiej (Rubus fruticosus). Pomeranian J Life Sci 2016;62(4):52-9. doi: 10.21164/pomjlifesci.269.

14. Nowak A, Zielonka-Brzezicka J, Pechaiko D, Tkacz M, Klimowicz A. Ocena właściwości antyoksydacyjnych liści Ginkgo biloba L. po zakończeniu wegetacji. Pomeranian J Life Sci 2017;63(1):24-30. doi: 10.21164/pomjlifesci.222.

15. Napoli E, Siracusa L, Ruberto G, Carrubba A, Lazzara S, Speciale A, et al. Phytochemical profiles, phototoxic and antioxidant properties of eleven
Hypericum species - A comparative study. Phytochemistry 2018;152:16273. doi: 10.1016/j.phytochem.2018.05.003.

16. Béjaoui A, Salem IB, Rokbeni N, M'rabet Y, Boussaid M, Boulila A. Bioactive compounds from Hypericum humifusum and Hypericum perfoliatum: inhibition potential of polyphenols with acetylcholinesterase and key enzymes linked to type-2 diabetes. Pharm Biol 2017;55(1): 906-11. doi: 10.1080/13880209.2016.1270973.

17. Wianowska D, Wiśniewski M. Simplified procedure of silymarin extraction from Silybum marianum L. Gaertner. J Chromat Sci 2015;53(2):36672. doi: 10.1093/chromsci/bmu049.

18. Gawlik-Dziki U, Kowalczyk D. Wpływ warunków ekstrakcji na aktywność przeciwutleniającą ekstraktów z kiełków rzodkiewki. Żywn Nauka Technol Jakość 2017;1(50):132-9.

19. Pawlak S, Sielicka M. Wpływ rozpuszczalnika zastosowanego do ekstrakcji na oznaczoną zawartość związków fenolowych i aktywność przeciwutleniającą wytłoków z aronii. In: Górecka D, Pospiecha E, editors. Zagospodarowanie ubocznych produktów przemysłu spożywczego. Poznań: Uniwersytet Przyrodniczy w Poznaniu; 2016. p. 25-33.

20. Wang J, Sun B, Cao Y, Tian Y, Li X. Optimization of ultrasound-assisted extraction of phenolic compounds from wheat bran. Food Chem 2008;106(2):804-10. doi: 10.1016/j.foodchem.2007.06.062.

21. Newerli-Guz J. Przeciwutleniające właściwości majeranku ogrodowego Origanum majorana L. Probl Hig Epidemiol 2012;93(4):834-7.

22. Kiewlicz J, Malinowska P, Szy musiak H. Aktywność przeciwrodnikowa wybranych wyciągów ziołowych. Probl Hig Epidemiol 2013;94(2):317-20. 